occasion I have seen him and he commenced to take the horacite, he begaii to pass fragments of stone, and "although they have sometimes caused pain in coming through the urethra, there has only once been any hæmorrhage and that very slight." The fragments thus expelled weigh two drachms, and consist mainly of uric acid with a slight coa ${ }^{2}$ ing on some of them of phos. phates.

In closing these remarks, which, though arising out of geographical considerations relative to the subject-matter, have been somewhat discursive, I feel that as in other cases of preventable disorders that of stone, particularly when it occurs in endemic proportions, is deserving of further notice. It is a symptom and not a disease.

I have read with satisfaction in an issue of the Indian Medical Gazette specially deroted to the subject of stone (August, 1900), that my friend Dr. Keegar, whose work in India has so largely contributed to our knowledge, suggests that the Government of India, in places where stone in the bladder is so common, should supply the most modern instruments necessary for its treatment, and thus save large number of lives. I would go a step further and see if measures could not be taken to prevent concretion occulring I cannot help thinking that more might be done in this direction, and that this aspect of the question is worthy of the consideration of so important a gathering.

\section{Service flotes.}

IMITATION is the sincerest form of flattery, we are told, bence the readers of this paper may read with interest of the proposal to establish a Medical Service for the American possessions atiroad on the lines of the Indian Medical Service. The following is an extract from the draft of the bill submitted to the Senate:-

"To establisb a permanent Medical Corps similar to the British East Indian Medical Service, whose duty it will be to serve the military and eivil services of the United States in those countries which, while under the United States Government, are separated as to their people and country from the United Stites proper. It is felt that properly qualified medical men will not come in sufficient numbers to the tropics to enable the officials and other civil employees of the Government to obtain that expert medical attention which they would receive in the United States, unless incentive is offered them; that men who have not devoted time and study to tropical surgery and medicine cannot attain to that proficiency which will be given by those who are specially trained for this work.

"Men experienced as medical ufficers are accustomed to sustain discipline and render loyal allegiance when acting under the orders of superiors. The provisions of this measure at once place a body of men trained in Medical military tropical service at the command of the United States, to be used either by the civil or military au thorities as the necessities may require.

"That when serving under the authority of the civil governments they must be subject to and act under civil law and civil

- "Thperiors. a better quality of medical service may be had for less cost.

"That these men are needed particularly in the care of the constabulary, and "ther native forces, and in the management of epidemic disease, falling under the jurisdiction of civil govern. ments, as well as to replace in the army those volunteer surgeons who are soon to be discharged by expiration of law, and the contract surgeons who are now employed in the tropics."

It may be noted that this service is to provide medical officers for both civil and military employment.

Some officers of the Indian Medical Service in Calcutta gave, on Saturday night, February 7 th, a most successful complimentary dinner to Mr. Jonathan Hutchinson, F.R.S., F.R.C.s., who is now a visitor in India.

Lieutenant-Colonel Ranking was in the chair, and in addition to the guest of the evening and his son, Mr. R. J. Hutchinson, H. H. the Lieutenant Governor of Bengal, Mr. Bourdillon; Colonel T. H. Hendley, C.I.E., I.M.s.; and Colonel B. O'Brien, I.M.S., were guests. The following l.M.S. officers were hosts :-Captain R. Bird, Lieutenant-Colonel Bomford, Major W. J. Buchanan, Lieutenant-Colonel R. H. Charles, Captain T. H. Delany, Captain B. H. Deare, Lieutenant-Colonel E. Dobson, Major F. C. Drury, Lieutenant-
Colonel Gibbons, Lieutenant-Colonel G. A. Harris, Captain T. H. Kelly, Captain Harold Meakin, Captain J. Mulvany, Lieutenant-Colonel R. D. Murray, Lieutenant-Colenel Peck, Major Pilgrim, Major Prain, Captain Rait, Lieutenant Colonel Ranking, Captain L. Rogers, Lieutenant-Colonel R. L. Dutt, and Lieutenant-Colonel R. C. Sanders.

Lieutenant-Colonel Ranking proposed and Lieutenant.Colonei R. C. Sander: seconded the toast of the guest of the evening in felicitous speeches, after which Mr. Hutchinson returned thanks in a speech full of appreciation of the medical work he had seen since his arrival in India. The Lieutenant-Governor of Bengal also spoke in most appreciative terms of the work of the medical profession in India.

Captain B. H. Deare was in good voice, and as usual added much to the success of the dinner by his fine singing.

“ BART.'s" Hospital was strongly in evidence at the Hutchinson Dinner, viz., Mr. J. Hutchinson himself, Colonel Hendley, Lieutenant-Colonel Bomford, Lieutenant-Colonel Ranking, Captain Bird, Captain Meakin, Captain Kelly and Major H. Pilgrim.

Of the London Hospital where Mr. J. Hutchinson had worked, so many years there were as representatives, Lieutenant-Colonel R. C. Sanders (retd.) and Captain J. Mulvany.

Captain G. O. F. Sealy, I.M.s., is employed on plague duty in the Central Provinces.

The services of Major O. Pinto, I.M.S., on return from leave, are placed at the disposal of the Military Department.

MAJOR GEE, I.M.S., has gone to Somaliland for field service.

Lieutenant W. H. CAZALY, I.M.S., officiates as Medical Officer, 25th Bo. Rifles, vice Captain R. W. Anthony, I.M.s., who has gone into civil employ.

Lieutenant-Colonel H. St. C. Carluthers, I.M.S., Medical Storekeeper to Government, Madras, has returned from England.

CAPTAin G. H. BaKer, I.M.S., is posted as Civil Surgeon of Cawnpore, and Lieutenant-Colonel J. F. Maclaren, I.M.S., as Civil Surgeon of Allahabad.

Captain T. W. A. Fullerton, I.M.S., is again placed on special plague duty in Allahabad District.

WE regret to record the death of Honorary Major J. Forsyth, I.S.M. Department, for many years in medical charge of the Viceroy's Staff.

Lieutenant-Colonel Fenn, R.A.M.C., Surgeon to the Viceroy, goes home on promotion, and is succeeded by Captain Armstrong, I.M.S., who acted for Colonel Fenn during last hot weather.

THE services of Lieutenant Mackelvie and Lieutenant E. O. Thurston, I.M.S., are to come to Bengal for eivil employ.

Lieutenant J. FOREst, I.M.s., was ordered to assume medical charge of the 11th Coorg Infantry and the Boer Camp Hospital.

THE services of Captain H. Kirkpatrick, I,M.S., are placed permanently at the disposal of the Government of Madras.

The following promotions and appointment have been made among Agency Surgeons under the Foreign Department with effect from the dates specified :-

Corsequent on the delocalisation of the appointment of Civil Surgeon of Quetta (which was formerly a localised appointment of the first clas $\triangleleft$ ), and with effect from the 25th October 1902-

Lieutenant-Colonel P. A. Weir, M.B., Indian Medical Service (Bengal), an Agency Surgeon of the 2nd (officiating lst) elass and Officiating Administrative Medical Officer in Central India, to be an Agency Surgeon of the 1st class.

Consequent on the death of the late Colonel A. H. C. Dane, M.D., Indian Nedical Service (Bombay), an Agency Surgeon of the first class having been placed at the disposal of His Excellency the Commander-in-Chief in India, and with effect from the 30 th October 1902

Lieutenant-Colonel J. Crofts, M.D., Indian Medical Service (Bengal), an Agency Surgeon of the 2nd class, to be an Agency Surgeon of the 1st class.

Captain J. W. Grant, м.в., Indian Medical Service (Bengal), is confirmed as an Agency Surgeon of the 2nd class, with effect from the 30th October 1902 .

Lieutenant-Colonel P. A. Weir, M.B., Indian Medical Service (Bengal), an Agency Surgeon of the 1st class, is confirmed as Administrative Medical Officer in Central India, with effect from the 30th October 1902, vice the late Colonel A. H. C. Dane, M.D., I.M.S. 
Liedtenant-Coloned M. D. Moriarty, M.D., I.M.S., is promoted Colonel to date from 25th October 1902, vice Colonel G. $\mathrm{MlcB}$. Davis retired.

The services of Military Assi-tant-Surgeon T. Baldry are placed at the disposal of Government of Bengal for civii employment.

ON return from leave Major R. J. Marks, I.M.S., is posted as Civil Surgeon of Bijnor, U. P.

ON the promotion of Colonel M. D. .1 oriarty, I.M.S., LieutenantColonel J. F. MacLaren, I.M,S., becomes a Civil Surgeon, 1st class.

ON the return from S. Africa of Lieutinant-Colonel S. J. Thomson, C.I.E., I.M.S., Major J. Chay tor-White, I.M.S., reverts to his appointment as Deputy Sanitary Commissioner, 1st Circle, U. P.

Captain G. Hutcheson, i.M.s., is posted on plague duty, 1 eerut District, as a temporary measure.

ON return from furlough the services of Major O. Pinto, I.M.S., are placed at disposal of the Home Department.

THE R. I. M. S. Hordinge has been fitted up as a Hospital Ship for the Somaliland Field Force.

THE Journal of Tropical Medicine of 1st January contains a portrait of Major Ronald Ross., I.M.s. (retired.)

MAJOR G. H. BAKER, I.M.S., is transferred as Civil Surgeon from Agr:i to Cawnpore on Lieutenant-Colonel H. P. Lukis, I.M.S., going to Agra.

Lieutenant-Colonel F. J. MacLaren, i.m.S., goes to Allahabad as Civil Surgeon, vice Lieutenant-Colonel B. O'Brien, I.M.S., promoted.

THE services of the following Medical Officers were placed at the disposal of the Punjab Government for plague duty:Captain S. B. Smith, I.M.s. ; Captain P. B. Haig, I.M.S. ; Cantain R. G. Turner, I.M.s.; ( 'aptain S. A. Harris, I.M.S.; Captain W. E. Scott-Moncrieff, I.M.S.

Captain P.' W. O'GuRman, M.D., D.PH., reverted to Civil Employ in the Punjab on the return of Lieutenant-Colonel D. P. Nacdonald from furlough.

Captain E. G. R. Whitcombe, I.M.S., was appointed to act a Civil Surgeon of Jacobabad on 1st January in addition to hi regimental duties.

Assistant-Surgeon P. A. CORDEIro was appointed to act as Civil Surgeon of Panch Mahals on 10th January.

Sir W. WILSON, R.A.M.c., who was P. M. O. in the Transvaal, has been commissioned to write the medical history of the war.

A movement has been started in America to erect a memorial to Major Walter Reed of the United State Army Medical Department, whose name will be remembered in connection with the mosquito theory of yellow fever.

MAJOR J. T. DALY, I.M.S., 9th Gurkha Rifles, is granted furlough for one year.

THE Secretary of State has sanctioned the following conditions in order to place the probationers of the Indian Medical Service on the same footing as those of the Royal Army Medical Corps : (1) Their title is changed from Surgeon on Probation to Lieutenant on Probation. (2) Their pay (exclusive of allowances) is raised to $14 s$. a day. (3) Their commission as Lieutenant bears the date on which their course of instruction in England com mences. They will not, however, be gazetted until they pass the final examination. (4) A Lieutenant on probation, who at the time of passing the examination for admission to the Indian Medical Service holds or is about to hold a resident appointment in a recognised Civil Hospital, may be seconded for a period not exceeding one year, during which he will receive the appointment. While seconded he will receive no pay from the Indian funds but his service will reckon towards promotion, increase of pay and pension.

Lieutenant A. R. Greenwood, R.A.M.c., and Lieutenent J. Cameron, I.M.s., are ordered to join to General Hospital at Berbera.
Captain BirRell, R.a.M.C., becomes Personal Assistant to P. M. O., Punjab Command.

Every year more and more Indian Medical Service Officers join the ranks of those who have written a book, and as we write, two new books lie on the table, viz., Major J. T. Calvert's "Intestinal Parasites" (Bengal Secretariat Press) and Major D. Simpson's "Infants their Ailments and Treatment in India"-hoth most useful books, which we will notice at length in our next issue.

MAJOR TAIT, R.A.M.C., is appointed to the medical charge of Army Head Quarters, or, as it used to be called, Surgeon to the Commander-in-Chief.

THe following letter appeared recently in the Pioneer. It looks as if R. A. M. C. "increase of pay" was like the reeent P. \& $O$. "reductions" in fare :-

"The proposed new rates of pay for the R.A.M.C. in India have already been published in your columns with the comments on them made by the British Medical.Journal. That paper hesitates to regard them as satisfactory without further intorma. tion. It adds that comparison with European rates depends on the increased cost of living in India and upon the rate of exchange. The most important factor, however, is the legal equivalent of the sovereign in rupees for the legal equivalent of English pay and allowances is the least that can be given to medical officers in India from the date of the passing of the new Warrant, i.e., 1st April 1902. Otherwise, the Home Government will be compelled to add a clause to the Warrant stating that medical officers will be on a lower scale of pay while in this country. This equivalent of English pay and allowances forms the first item of Indian Consolidated Pay.

"For the second item I quote the Indian Army Regulations, Vol. 1, as follows :-

"In order that officers may be prepared at all times to move at the shortest notice, an allowance out of which they are required to provide and keep the camp equippage of their rank, carriage for its conveyance, and the requisite establishments, is included in the pay and Indian allowances of the several ranks as follows:Colonel, Rs. 200 ; Lieutenant-Colonel, Rs. 150 ; Major, Rs. 120 ; Captain, Rs. 75 ; Lieutenant, Rs. 50.'

The sum of these two items plus Exchange Compensation Allowance is therefore the exact legal equivalent of Home (not Allowance is therefore the exe a table below of Home rates, taken from the British Medical. Journal, and show the losses or gains involved by Indian service under the proposed new scale of pay.

\begin{tabular}{|c|c|c|c|c|c|c|}
\hline$\underset{\tilde{\Xi}}{\stackrel{\oplus}{\Xi}}$ & & 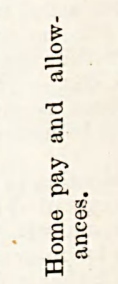 & 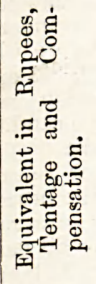 & 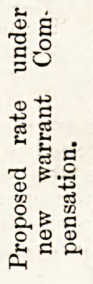 & 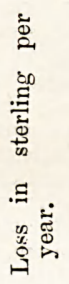 & 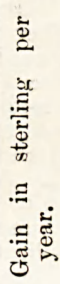 \\
\hline $\begin{array}{l}\text { Lieut } \\
\text { Capt } \\
\text { ", } 7 \text { yrs. } \\
\text {,, } 10 \text { yrs. } \\
\text { Major } \\
\text {," } 15 \text { yrs. } \\
\text { Lt.-Col. } \\
\text {,, Senior }\end{array}$ & $\begin{array}{l}\cdots \\
\cdots \\
\cdots \\
\cdots \\
\cdots \\
\cdots \\
. \\
\cdots\end{array}$ & $\begin{array}{cc}£ . & s . \\
323 & 10 \\
379 & 15 \\
400 & 0 \\
477 & 15 \\
587 & 12 \\
632 & 12 \\
713 & 15 \\
804 & 15\end{array}$ & $\begin{array}{r}\text { Rs. } \\
484 \\
585 \\
610 \\
712 \\
906 \\
964 \\
1,105 \\
1,278\end{array}$ & $\begin{array}{r}\text { Rs. } \\
445 \\
504 \\
562 \\
689 \\
838 \\
876 \\
1,121 \\
1,224\end{array}$ & $\begin{array}{r}£ \\
31 \\
65 \\
38 \\
18 \\
54 \\
70 \\
\dddot{43}\end{array}$ & 13 \\
\hline
\end{tabular}

To all the above losses add the Colonial allowance, say of Ceylon, and to the losses of Captains and Lieutenants add $£ 24$ a year horse allowance. It would be interesting to know who worked out the proposed rates and how he or they arrived at the conclusion that a junior Captain should lose $£ 65$ a year or a total of $£ 325$ on a tour of five years, while a senior Captain should lose only $£ 90$ in pay and allowances. Of course, they both lose $£ 120$ in addition in horse allowance, and a large amount in Colonial allowance. Why should a junior Lieutenant-Colonel in Colonial allowance. When one lose $£ 43$ ? It would be futile to bring forward again all the arguments as to the necessity of mounting junior medical officers. Practicaliy all of them own horses and cannot do their work without them. A question in Parliament would show what proportion of those ordered to the Delhi Ilanouvres were mounted at their own expense, and if the 
sick conld have been efficiently attended if this had not been the case. Again, it might be asked if a medical officer who been theady walked a round of two or three miles to his hospital and back to his quarters should be called upon to walk perhaps two miles more to attend an officer's child who is dying of heattwo miles more to attend an officer's child who is dying of heat
stroke. The withholding of horse allowance is significant of what the R. A. M. C. can expect from the Indian Government, but it must be confessed that the senior officers of the Corps are partly responsible for not forcing this urgently needed reform upon the responsible for not forcing this urgently ne Government has taken up towards the R. A. M. C. is a most extraordinary one, for to give its members less pay than they receive in England is an unjust and, in view of the attitude of the medical profession, an impossible policy."

IN continuation of the Editorial on I. M. S. men in the Dictionary of National Biography which we published in our January number (p. 23) Lieutenant-Colonel D. G. Crawford, I.M.S., now on (p. 23), Lieutenant-Colonel

Vol. i. Anderson, James, Madras.

Vol. 25. Harwood, Sir Bussick, 1764-1778.

Vol 35. Macneill, Sir John, G.C.в. (Bo mbay).

Vol. 51. Scott, Helenus (Bombay). Miedical Service and was,
Harwood belonged to the Bengal Med after his retirement, appointed Professor of Anatomy, and Downing Professor of Medicine at Cambridge.

Lieutenant-Colonel Crawford also informs us that Simon LIEUTENANT-COLONEL CRA we a note in these columns in last Nicolson, about whom we gave a died in Calcutta on 7 th August 1855 or only seven days after his retirement.

THE Sir John "acneill mentioned above served for twenty years in the Bombay Medical Service, was made a G.C.B., a Privy in the Bombay Medical Service, officers who attained to these three high distinctions.

DURING the absence of Lieutenant-Colonel R. E S. Davis, I.M.S., at the Delhi Durbar, Captain Stodart performed the duties of Civil Surgeon, Rangoon.

Lieutenant L. B. Scott, I.M.S., takes civil medical charge of Roorkee, vice Major William Dawson, I.M.S., on leave.

MAJOR R. J. MARKS, I.M.S., on return from leave, is posted as Civil Surgeon to Bijnor.

WE republish the following :-

“UDU ExaMINaTion.Candidates who fail to pass in Urdu, by either the lower or higher standard. will be furnished with the proceedings of the Board before whom they appeared for examinproceedings of the Board $\mathrm{x} 831$ or X 832, as the case may be), immediately the final decision has been recorded thereon, the rank, name, and corps of the candidate being entered on the form before it is despatched to him.

2 A candidate who is for re-examination in one subject only will be careful to preserve the proceedings of the Board furnished to him under the preceding paragraph, and will attach them to his application when submitting his name for re-examination. Should the candidate be for re-examination in either subject $(a)$ or $(b)$, the the candidate be for re-examinatination will be transmitted to the proceedings of the former examinal Board with the indent (India Army Form X 783) for the necessary papers.

3. The above procedure obviates the use of the form (India Army Form X 784) referred to in G. O. C. C.'s Nos. 507 and 544 of 1902 , which are hereby cancelled.

Military Assistant-Surgeon W. H. Harding is granted combined leave for 8 months and 18 days.

Liedtenant-Colonel C. P. Lukis, I.M.S., lecomes a Civil Surgeon, 1st Class, vice Colonel B. O'Brien, I.M.s., promoted.

Lieutenant-Colonel J. L. Poynder, I.M.S., has been granted 4 months' extension of leave on medical certificate.

Captain N. R. J. Rainier, I.M.s., has been granted 6 months' extension of leave on medical certificate.

MAJOR D. T. LANE, I.M.S., has been granted 4 months' extension of furlough, and Captain S. R. Douglas, I.M.S., 5 months.

MaJor D. M. Davidson, I.M.s., is confirmed as a Civil Surgeon, 1st Class, Punjab, on the retirement of Lieutenant-Colonel B. Doyle, I,M.S.
MaJOR P. W. O'GORMan, I.M.S., M.D., D.P.H., is appointed Civil Surgeon of Karnal.

Honorary Lieutenant J. T. Weston, I.S.M.D., has got furlough for one year.

THE services of Captain G. McI. C. Smith, I.M.S., are placed at the disposal of thePun jab Government.

Promotion on the Bombay side is going fast. The services of Lieutenant-Colonel Greany, i.M.S., and of Lieutenant-Colonel J. McCloghry are placed at the disposal of the Commander-in-Chief.

ON the Bengal side the air is full of rumours of promotion, owing to retirements and taking of leave.

CAPTAIN T. JACKson, I.M.S., M.B., is appointed Civil Surgeon of Hyderabad, Sindh, during the absence on leave of LieutenantColonel Stevenson, I.M.s.

Lieutenant-Colonel W. G. H. Henderson, I.M.S., F.R.C.S.I., is appointed Civil Surgeon of Poona, vice Lieutenant-Colonel Greany, promoted to administrative rank, and Major M. A. T. Greany, promoted to administrative rurgeon, 3rd District, vice Lieutenant-Colonel Henderson.

Captain H. M. Moore, I.M.s., is appointed Resident Surgeon, St. George's Hospital, Bombay.

As we go to press it is announced that Lieutenant-Colonel S. Haslett Browne, M.D., C.I.E., has been appointed to succeed Colonel Hendley, C.I.E., as Inspector-General of Civil Hospitals, Bengal.

MaJor R. J. Macnamara, I.M.S., the Senior Officer in the Punjab Jail Department, will officiate for N!ajor W. J. Buchanan, I.M.S., as Inspector-General of Jails, Bengal, on the latter going on 10 months' leave in the middle of April.

\section{ghatice.}

Scientific Articles and Notes of Interest to the Profession in India are solicited. Contributors of Original Articles will receive 25 Reprints gratis, if requested.

Communications on Editorial Matter's, Articles, Letters and Books for Review should be addressed to THE EDITOR, The Indian Medical Ğ(zette, c/o Messrs. Thacker, Spink \& Co., Calcutta.

Communications for the Publishers relating to Subscriptions, Advertisements and Reprints should be addressed to The Publishers, Messis. Thacker, Spink \& Co., Calcutta.

Annual Subscriptions to the Indian Medical Gazette, Rs. 12, including postage.

\section{BOOKS, REPORTS, \&c., RECEIVED.}

Bombay Dispensaries Annual Report.

Administration Report, Hyderabad Assigned States.

History of Hooghly. By Lt.-Col. D. G. Crawford, I.M.s.

Birch's Management of Children in India. New Edition. (Thacker, Spink \& Co.)

Infants and their Ailments. By Major D. Simpson, I.M.s. (Thacker,

Spink \& Co.)
Plague Manual for Bengal (Secretariat Press).

Intestinal Parasites. By Major J. T. Calvert, I.M.s. (Secretariat Press).

Diseases of the Skin. By Radcliffe Crocker. 3rd Ed., 2 Vols. (H. K.

Lewis.)
Constipation. By Sherman Bigg (Ballière, Tindall \& Cox).

Punjab Administration Report.

\section{LETTERS, COMMUNICATIONS, RECEIVED FROM :-}

Major J. T. Walsh, I.м.s., Berhampur; Major D. M. Moir, I.st s., Calcutta ; Capt. E. R. Rost, I.M.s., Rangoon; Major A. Buchanan, I.M.s., Khandwa, C. P. ; Major H. Herbert, I.M. M.s., Bombay; Lieut. F. w. Sumner, I.M. S., Mian Mir; Lt.-Col. D. G. Crawford, I.M.S., London; Dr. W. Daniels, London; Major R. Ross, Liverpool ; Major W. D. Suther: land, I. M.s., Saugor; Capt. R. H. Elliot, I.M.s., Mentone, 